\title{
EVALUASI EFISIENSI PENYELENGGARAAN PENDIDIKAN SEKOLAH DASAR DAN MADRASAH IBTIDAIYAH DI KALIMANTAN TIMUR ${ }^{1}$
}

\author{
Suripto \\ Peneliti Muda pada Pusat Kajian Kinerja Kelembagaan \\ Lembaga Administrasi Negara, Jl. Veteran No. 10 Jakarta Pusat \\ Email: suripto3x@rocketmail.com atau rivto76@yahoo.co.id
}

\begin{abstract}
Education is the right of every citizen. East Kalimantan Province has a 12-year free education program. Gross enrollment ratios Primary School level in 2009 reached 112.30 percent and high school level GER ranked fourth nationally. On the other hand, East Kalimantan Province also has limitations in education facilities and infrastructure. Some barriers are factors such as land area, population distribution is uneven and limited transportation infrastructure. With these achievements and constraints, it is necessary to evaluate the education in East Kalimantan province. Furthermore, in conducting the evaluation used data analysis tools Envelopment Analysis (DEA) model of Banker Charnes and Cooper (BCC) with output orientation. Results Analysis showed that District/Municipality covers a relatively efficient Paser District, Berau District, Manilau District, Balikpapan Municipality, Samarinda Municipality Penajam Paser District, Tarakan Municipality, East Kutai District, West Kutai District, and Bontang Municipality. While the relatively inefficient covering Kutai Kartanegara District, Bulungan District, Nunukan District, District/Municipality that became a reference in the increased efficiency is Paser District, Berau District, Samarinda and Bontang Municipalities. Furthermore, the Municipality of Samarinda is the most efficient evaluation unit and at most be a reference to increased efficiency.
\end{abstract}

Keywords: evaluation, education, eficiency, and East Kalimantan.

\section{Intisari}

Pendidikan adalah hak setiap warga Negara. Provinsi Kalimantan Timur (Kaltim) telah memiliki program pendidikan gratis 12 tahun. Angka Partisipasi Kasar (AKP) jenjang Sekolah Dasar (SD) pada tahun 2009 mencapai 112,30 persen dan APK jenjang Sekolah Menengah Atas (SMA) Kaltim menempati urutan ke-empat nasional. Disisi lain,

${ }^{1}$ Naskah diterima: 1 Desember 2010, revisi kesatu: 17 Februari 2011, revisi kedua: 7 Maret 2011. 
Provinsi Kaltim juga menghadapi kendala keterbatas dalam sarana dan prasarana pendidikan. Kendala tersebut disebabkan beberapa faktor antara lain luasnya wilayah, penyebaran penduduk yang tidak merata dan terbatasnya prasarana trasportasi. Dengan prestasi dan Kendala tersebut, maka perlu dilakukan evaluasi penyelenggaraan pendidikan di Provinsi Kaltim? Selanjuntya, dalam melakukan evaluasi digunakan alat analisis Data Envelopment Analysis (DEA) model Banker, Charnes, dan Cooper (BCC) dengan orientasi output. Hasil Analisis menunjukan bahwa kabupten/kota yang relatif efisien meliputi Kabupaten Paser, Kabupaten Berau, Kabupaten Manilau, Kota Balikpapan, Kota Samarinda, Kabupaten Kutai Barat, Kabupaten Kutai Timur, Kabupaten Penajam Paser Utara, Kota Tarakan. dan Kota Bontang. Sedangkan yang relatif belum efisien meliputi Kabupaten Kutai Kartanegara, Kabupaten Bulungan, Kabupaten Nunukan, Kabupten/kota yang menjadi referensi dalam peningkatan efisiensi adalah Kabupaten Paser, Kabupaten Berau, Kota Bontang dan Kota Samarinda. Selanjuntya, Kota Samarinda merupakan unit evaluasi yang paling efisien dan paling banyak menjadi referensi peningkatan efisiensi.

Kata kunci: evaluasi, pendidikan, efisien dan Kaltim

\section{A. PENDAHULUAN}

Pendidikan layak dan berkualitas adalah hak setiap warga negara. Oleh karena itu, negara memiliki tanggung jawab untuk menyediakan hal tesebut. Undang-Undang (UU) Sistem Pendidikan Nasional (Sisdiknas) nomor 20 tahun 2003 telah memberikan jaminan pada masyarakat untuk memperoleh pendidikan yang layak dan berkualitas. UU tersebut mengamanatkan pemerintah dan pemerintah daerah untuk menyelenggarakan program wajib belajar (wajar) minimal tanpa dipungut biaya. Penyelenggaraan pendidikan tersebut dibiayai dengan Anggaran Pendapatan dan B elanja Negara/Daerah (APBN/D) sebesar minimal 20 persen. Oleh karena itu, beberapa pemerintah daerah telah menyelenggarakan program pendidikan gratis, antara lain Provinsi Sumatera Selatan, Provinsi Sulawesi Selatan, Provinsi Sulawesi Tenggara, Provinsi Kalimantan Timur (Kaltim), Provinsi Jawa Barat, dan Provinsi DKI Jakarta ${ }^{2}$ Namun demikian, Penyelenggaran Pendidikan gratis bervariasi pada setiap pemerintah daerah, misalnya Provinasi DKI Jakarta masih membatasi pendidikan gratis untuk sekolah negeri, sedangkan Provins i Kalti m sudah melaksanakannya untuk sekolah negeri maupun swasta.

Dalam Rencana Pembangunan Jangka Menengah (RPJM) Daerah Provinsi Kaltim tahun 2008 - 2013, salah satu program pendidikannya adalah perluasan dan pemerataan akses pendidikan yang bermutu melalui wajar 12 tahun $^{3}$. Untuk itu, Pemprov

\footnotetext{
2 Mendiknas: Pendidikan Dasar Gratis Bisa Dilaksanakan http://www.diknas.go.id/headline.php?id=143

${ }^{3}$ Program membangun pendidikan di Kalimantan Timur, Orasi Ilmiah Gubernur Kalimantan Timur Pada Upacara Wisuda Um Semester Gasal 2009/2010 http://www.um.ac.id/news/2010/03/348/
} 
Kaltim mengalokasikan anggaran 2009/2010 untuk beasiswa mencapai Rp 94.241.860.000 yang diharapkan mampu memberikan bantuan kepada 24.649 penerima yang berasal dari 14 kabupaten/kota ${ }^{4}$. Anggaran tersebut merupakan bagian dari komitmen pemerintah untuk menganggarkan biaya pendidikan mencapai $20 \%$ dari total APBD Kaltim yang telah disepakati bersama dengan DPRD Kaltim, Pemkab/Pemkot beserta DPRD masing-masing.

Pendidikan di Provinsi Kaltim menunjukkan kemajuan yang sangat signifikan sejak otonomi daerah. Data Kementerian Pendidikan Nasional (Kemdiknas) tahun 2009 menunjukkan bahwa APK SMA/SMK/MA Kaltim telah menunjukkan angka $84 \%$ dan menempati urutan ke-empat nasional setelah DKI Jakarta, DI Yogyakarta dan Maluku'. Hal ini tentunya tidak terlepas dari tersediaya sekolah dan guru di seluruh Kaltim. Jumlah sekolah seluruh jenjang sebanyak 3.500 sekolah dengan 750.000 siswa dan 58.000 guru.

Disisi lain, Pemerintah Daerah Provinsi Kaltim juga menghadapi kendala keterbatas dalam sarana dan prasarana pendidikan. Hal ini disebabkan oleh beberapa faktor antara lain luasnya wilayah, penyebaran penduduk yang tidak merata dan terbatasnya prasarana trasportasi. Faktor transportasi misalnya belum ada jalan darat yang dapat menghubungkan antar wilayah desa dan kecamatan, khususnya daerah kabupaten. Kondisi geografis yang relatif sulit terjangkau tersebut tentu menjadi kendala dalam pembangunan infrastruktur sehingga penyebaran guru pun menjadi tidak merata $^{6}$.

Dengan mendasarkan pada prestasi yang telah dicapai dan kendala yang dihadapi Provinsi Kaltim, maka perlu dilakukan evaluasi penyelenggaraan pendidikan pada setiap kabupaten dan kota di Provinsi Kaltim. Evaluasi tersebut penting dilakukan untuk mengetahui tingkat efektifitas dan efisiensi dalam penyelenggaraan pendidikan. Selain itu, hasil evaluasi juga dapat dijadikan masukan dalam perencanaan pembangunan pendidikan Provinsi Kaltim selanjutnya.

Evaluasi adalah suatu proses penilaian pada sesuatu. Evaluasi berdasarkan proses dibagi dalam tiga tahap yakni tahap awal, tahap proses dan akhir. Evaluasi tahap awal dilakukan untuk menguji konsep dan rencana pelaksanaan. Evaluasi proses dilakukan untuk mengawal pelaksaan kegiatan supaya sesuai dengan rencana. Evaluasi akhir dilakukan untuk melihat tercapainya tujuan dan dijadikan analisa masukan kegiatan berikutnya. Selanjuntya, tujuan evaluasi adalah untuk mengetahui tingkat efektifas

\footnotetext{
${ }^{4}$ Kaltim Salurkan Beasiswa Rp 94,241 Miliar http://www.indonesia.go.id/id/index.php?option=com_content $\&$ task=view $\&$ id $=9938 \&$ Itemid $=831$

5 Kondisi Terkini Pendidikan Kaltim, Orasi Ilmiah Gubernur Kalimantan Timur Pada Upacara Wisuda Um Semester GasaL 2009/2010 http://www.um.ac.id/news/2010/03/348/

${ }^{6}$ Sarana Dan Prasarana Pendidikan Di Kalimantan Timur, http://mrtoy09.com/index.php?option=com_content $\&$ view $=$ article $\&$ id $=75:$ isu-isu-kritis-dalam pendidikan $\&$ catid $=43:$ artikelku $\&$ Itemid $=6$
} 
dan efisiensi dari suatu tahapan kegiatan ${ }^{7}$.

Kajian tentang evaluasi bidang pendidikan telah banyak dilakukan oleh berbagai pihak, baik secara individu, kelompok maupun institusi. Beberapa kajian tersebut antara lain Survai Publik Program Bontang Cerdas 2010 yang dilakukan oleh oleh Tim Pusat Kajian Pengembangan Manajemen Strategis dan Pemasaran (PKPMSP) Fakultas Ekonomi Unmul (2010) mengevaluasi 14 kriteria program Bontang Cerdas $2010^{8}$. Kajian penyelenggaraan akreditasi sekolah pada pendidikan dasar oleh Totok Sumaryanto F. seorang Dosen Universitas Negeri Semarang yang menghasilkan tiga hal yakni potensi dan permasalahan penyelenggaraan pendidikan dasar, kondisi dan efektifitas komponen penyelenggaraan akreditasi pendidikan dasar, dan pengembangan komponen dalam penyelenggaraan akreditasi pendidikan dasar ${ }^{9}$. Dengan melihat pada dua kajian tersebut, bahwa banyak variasi dalam melakukan evaluasi pendidikan. Evaluasi yang dilakukan PKPMSP sangat komprehensif tetapi hanya untuk satu wilayah pemerintah daerah Kota Bontang. Sedangkan kajian kedua melakukan kajian yang sangat mikro tetapi bersifat lebih general. Selanjuntya, kajian ini melakukan evaluasi hasil penyelenggaraan pendidikan tahun ajaran 2008/2009 di Provinsi Kaltim. Evaluasi ini menggunakan data pembangunan pendidikan di Provinsi Kaltim yang valid dan akurat. Data yang digunakan merupakan data yang disajikan dalam Kalimantan Timur dalam Angka 2009. Alasan penggunaan data tersebut didasarkan atas kenyakinan keakuratan data tersebut, sehingga dengan demikian akan memberikan hasil evaluasi yang juga akurat. Kajian ini tentunya tidak sekomprehensif indikator program Bontang Cerdas 2010 serta tidak semikro hasil kajian yang kedua. Namun demikian, evaluasi ini penting dalam meningkatkan efisiensi dalam penyelenggaraan pendidikan berdasarkan indikator yang dipilih.

Pendidikan di Provinsi Kaltim meliputi pendidikan formal dan non formal. Pendidikan formal antara lain Sekolah Dasar (SD), Madrasah Ibtidaiyah (MI), Sekolah Menengah Pertama (SMP). Madrasah Tsanawiyah (MTs), Sekolah Menengah Umum (SMU), Sekolah Menengah Kejuruan (SMK), Madrasah Aliyah (MA), Perguruan Tinggi, Universitas dan lain sebagainya. Sedangkan, pendidikan non formal antara lain kelompok belajar (kejar) paket A, kejar paket B, kursus dan bimbingan. Oleh karena itu, Evaluasi ini dibatasi pada penyelenggaraan dasar enam tahun yang meliputi sekolah dasar (SD) negeri, SD swasta, Madrasah Ibtidaiyah (MI) negeri dan MI swasta pada tahun 2008.

Model evaluasi pendidikan SD dan MI dilakukan secara parsial dan komprehensip. Parsial dilakukan

\footnotetext{
Suripto, Evaluasi Kinerja Pendidikan Dasar Kabupaten Dan Kota di Provinsi Gorontalo

${ }^{8} \mathrm{http}: / /$ www.kaltimpost.co.id/index.php?mib=berita.detail\&id=79928

${ }^{9}$ http://puslitjaknov.org/data/file/2008/makalah_peserta/02_totok\%20s_kajian\%20penyelenggaraan\%20 akreditasi\%20sekolah.pdf
} 
dengan mengevaluasi setiap jenis sekolah, sedangkan secara komprehensif dengan menggabungkan seluruh data sekolah secara bersamasama. Gambar Alur evaluasi evaluasi seperti pada gambar 1 .

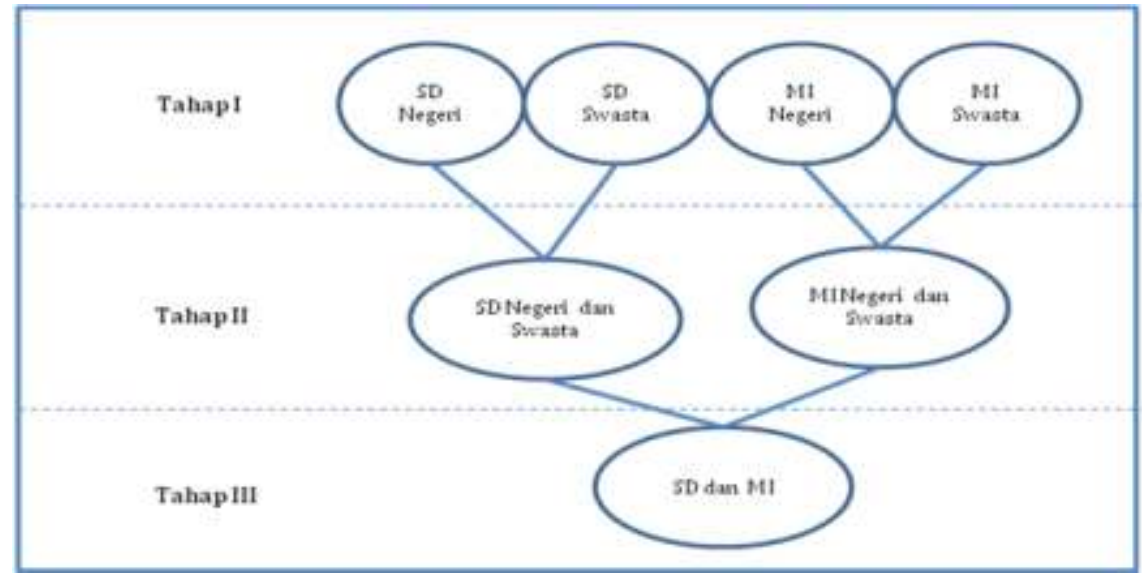

Gambar 1. Alur Evaluasi Pendidikan SD dan MI di Provinsi Kaltim

Evaluasi pendidikan SD dan MI Provinsi Kaltim dilakukan melalui tiga tahap. Tahap satu dilakukan dengan mengevaluasi SD negeri, SD swasta, MI negeri dan MI swasta. Tahap dua dilakukan dengan menggabungkan data SD negeri dan SD swata, MI negeri dan MI swasta di evaluasi secara bersama-sama. Tahap tiga dilakukan dengan menggunakan data keseluruhan sacara bersama-sama. Hal ini dilakukan untuk mengetahui keunggulan dan kelemahan dari setiap kabupaten dan kota dalam penyelenggaraan setiap jenis sekolah.

\section{B. ALATANALISIS}

Alat analisis yang digunakan dalam evaluasi pendidikan SD dan MI di Provinsi Kaltim adalah Data Envelopment Analysis (DEA). Dimana, DEA merupakan salah satu tool yang dapat mengukur tingkat relative efisiensi organisasi dengan membandingkan antara input dengan output (Cooper et al, 2006) ${ }^{10}$. Sehingga, hasil evaluasinya adalah menentukan tingkat dan nilai efisien dan tidak efisien DMUs. Oleh karena itu, alat ini dapat digunakan untuk mengukur organisasi publik maupun swasta. Bahkan, Oyama : 2008 dalam Toni Bahtiar, Materi Metodologi dan Alat Analisis Kajian Evaluasi Pelayanan Dasar (2009) berpendapat bahwa DEA merupakan salah satu teknik dalam operation research yang cukup sering digunakan dalam sektor publik. Dalam DEA, objek evaluasi disebut dengan Decision Making Unit (DMU). Dengan demikian, DMU dalam evaluasi ini adalah pemerintah daerah kabupaten dan kota di Provinsi Kaltim.

\footnotetext{
${ }^{10}$ Cooper, William W., Seiford, Lawrence M., and Tone, Kaoru, (2006) Data Envelopment Analysis : A 
Setiap alat analisis memiliki keunggulan dan keterbatasan. DEA sebagai alat analisis memiliki keunggulan antara lain sistem kerja DEA yang relatif sederhana; memberikan peringkat dan nilai tingkat efisiensi dari setiap DMU; memberikan nilai proyeksi dalam peningkatan efisiensi DMU; serta mampu memberikan referensi DMU yang paling sesuai dalam meningkatkan efisiensinya. Sedangkan limitasi DEA antara lain tidak dapat digunakan dengan angka 0 (nol).

DEA memiliki model dan jenis yang bervariasi. Salah satunya adalah model Banker, Charnes, dan Cooper (BCC), model ini memiliki pilihan orientasi input atau output. Pengukuran dengan orientasi input didasarkan pada upaya pengurangan penggunaan input secara proporsional dengan menjaga tingkat ouput konstan. Sedangkan pengukuran efisiensi teknis dengan orientasi output didasarkan pada upaya peningkatan output secara proporsional dengan menjaga tingkat input yang digunakan konstan. Dalam evaluasi pendidikan SD dan MI Provinsi Kaltim didasarkan pada orientasi output (DEA-BCC Output). Pemilihan model ini didasarkan atas focus yang dihasilkan dalam perbaikan indikator output. Model BCC berorientasi output untuk DMU ke-i secara matematik dinyatakan sebagai sebuah pemrograman linear berikut ":

$$
\begin{array}{cl}
\max _{E, \lambda} & E \\
\text { s.t. } & X \lambda \leq x_{i} \\
& E y_{i}-Y \lambda \leq 0 \\
& e \lambda=1 \\
& \lambda \geq 0
\end{array}
$$

dengan E adalah tingkat efisiensi yang akan dihitung dan dimaksimumkan, $\mathrm{X}$ dan $\mathrm{Y}$ berturut-turut adalah matriks input dan matriks output, xi dan yi berturut-turut adalah vektor kolom ke-i dari matriksmatriks $\mathrm{X}$ dan $\mathrm{Y}$ yang berkaitan dengan DMU ke-i, e adalah vektor baris yang semua elemennya 1 , dan adalah vektor kolom dengan elemen-elemen tak negatif.

Selanjutnya, indikator yang digunakan DEA-BCC-output meliputi indikator input dan output. Indikator input meliputi jumlah sekolah (sklh), jumlah guru (gr), sedangkan indikator outputnya adalah jumlah siswa (sw). Pemilihan indikator input didasarkan pertimbangkan indikator tersebut menentukan tingkat efisiensi output. Hal lainnya yakni indikator tersebut merupakan data yang tersaji dalam Kalimantan Timur Dalam Angka 2009, sehingga dapat disimpulkan bahwa data tersebut menjadi indikator dalam keberhasilan pembangunan pendidikan.

Banyak indikator yang dapat menentukan efisiensi penyelenggraan pendidikan antara lain anggaran, siswa, sekolah, kelas, fasilitas dan lain sebagainya. Namun demikian sebagaimana telah dijelaskan diatas dalam evaluasi ini menggunakan data dalam Kalimantan Timur Dalam Angka 2009. Indikator yang digunakan sebagai input adalah jumlah sekolah dan jumlah guru, sedangkan outputnya adalah jumlah siswa. Selanjutnya, proses evaluasi seperti pada gambar 2.

\footnotetext{
${ }^{11}$ Toni Bahtiar, 2009, Materi Metodologi Kajian Evaluasi Pelayanan Dasar, Pusat Kajian Kinerja Kelembagaan 2009 .
} 


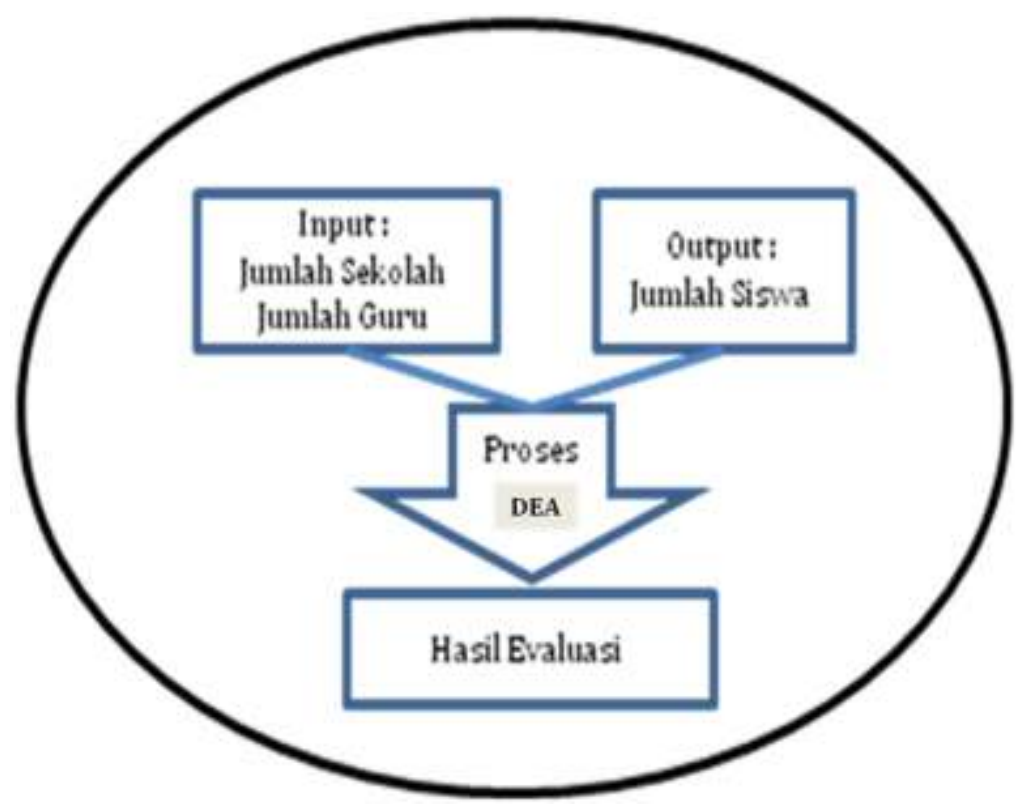

Gambar 2. Proses Evaluasi Dengan DEA-BCC-Output

\section{DESKRIPSI PENDIDIKAN SD DAN MI PROVINSI KALTIM}

Secara administratif Provinsi Kaltim terbagi menjadi 4 kota dan 10 kabupaten yang meliputi 136 kecamatan dan 1,422 desa/kelurahan. Luas wilayah Provinsi Kaltim adalah 20.865.744 ha yang terbagi daratan seluas 19.844.177 ha dan laut seluas 1.021.567 ha. Kabupaten dan Kota di Provinsi Kaltim meliputi Kabupaten Berau ( $\mathrm{Kb} \mathrm{Br}$ ), Kabupaten Bulungan (Kb Blg), Kabupaten Kutai Barat (Kb
KB), Kabupaten Kutai Kartanegara (Kb KK), Kabupaten Kutai Timur (Kb KT), Kabupaten Malinau (Kb Mln), Kabupaten Nunukan (Kb Nn), Kabupaten Paser (Kb Pr), Kabupaten Penajam Paser Utara (Kb PPU), Kabupaten Tana Tidung (Kb TT), Kota Balikpapan (Kt BP), Kota Bontang (Kt Btg), Kota Samarinda (Kt Smrd), dan Kota Tarakan ( Kt Tr). Selanjuntya, penyebaran desa dan kelurahan kabupaten dan kota seperti pada grafik 1 .

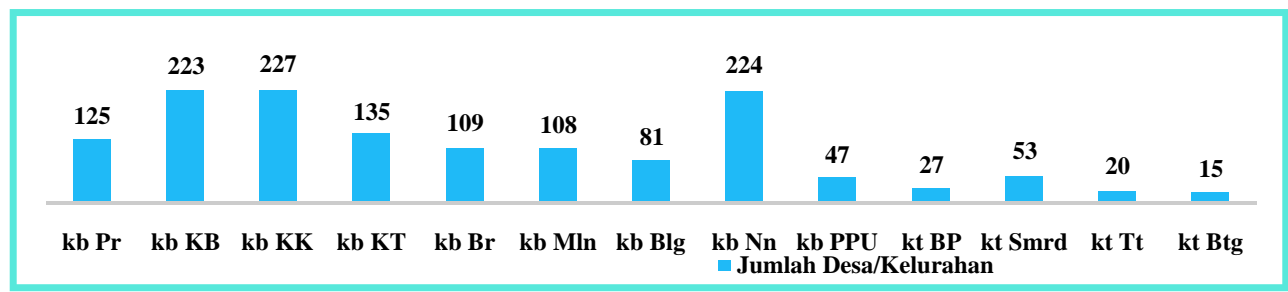

Sumber : Kalimantan Timur Dalam Angka 2009

Grafik 1. Jumlah Desa/Kelurahan di Provinsi Kaltim 
Penduduk Provinsi Kaltim pada tahun 2008 sebanyak 3.094.700 jiwa ${ }^{12}$. Penyebaran penduduk tidak merata, Data tahun 2008 menunjukan bahwa Kota Samarida $(19,50$ persen $)$, Kabupaten Kutai Kartanegara $(17,08$ persen), Kota Balik Papan (16,50 persen) dan lainnya tersebar dengan kisaran 1 - 6 persen. Bila dibandingkan dengan luas wilayah, maka Kota dengan luas wilayah hanya 1,13 persen ditempati oleh penduduk sebanyak 53,83 persen. Sedangkan luas dan penduduk lainnya tersebar di kabupaten. Penyebaran penduduk tahun 2008 seperti pada grafik 2 .

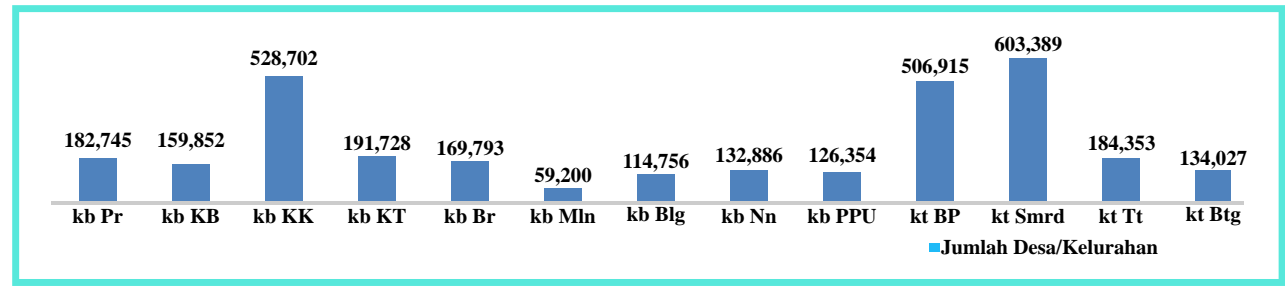

Sumber : Kalimantan Timur Dalam Angka 2009

Grafik 2. Penyebaran Penduduk Provinsi Kaltim

Selanjutnya dalam bidang pendidikan, Provinsi Kaltim secara umum mengalami perkembangan yang baik. Hal ini dapat dilihat pada Angka Partisipasi Kasar (AKP) jenjang SD tahun 2009 mencapai 112,30 persen ${ }^{13}$. Penyebaran Sekolah, Guru dan Siswa SD dan MI Provinsi Kalimantan Timur tahun 2008 seperti pada tabel 1.

Tabel 1. Penyebaran Sekolah, Guru dan Siswa SD dan MI Provinsi Kaltim

\begin{tabular}{|c|c|c|c|c|c|c|c|c|c|c|c|c|c|}
\hline \multirow{3}{*}{ NO } & \multirow{3}{*}{ KAB/KOTA } & \multicolumn{6}{|c|}{ SD } & \multicolumn{6}{|c|}{ MI } \\
\hline & & \multicolumn{3}{|c|}{ Negeri } & \multicolumn{3}{|c|}{ Swasta } & \multicolumn{3}{|c|}{ Negeri } & \multicolumn{3}{|c|}{ Swasta } \\
\hline & & Sklh & Sw & $\mathrm{Gr}$ & Sklh & $\mathrm{Sw}$ & $\mathrm{Gr}$ & Sklh & $\mathrm{Sw}$ & $\mathrm{Gr}$ & Sklh & $\mathrm{Sw}$ & $\mathrm{Gr}$ \\
\hline 2 & $\mathrm{~Kb} \mathrm{~KB}$ & 218 & 23,607 & 1,637 & 5 & 910 & 54 & - & - & - & 5 & 381 & 43 \\
\hline 3 & $\mathrm{~Kb} \mathrm{KK}$ & 432 & 72,427 & 4,811 & 15 & 1,954 & 109 & 2 & 583 & 43 & 21 & 2,023 & 199 \\
\hline 4 & $\mathrm{~Kb} \mathrm{KT}$ & 161 & 24,272 & 1,876 & 14 & 3,739 & 235 & 1 & 320 & 23 & 4 & 630 & 29 \\
\hline 5 & $\mathrm{~Kb} \mathrm{Br}$ & 151 & 22,305 & 1,609 & 5 & 1,640 & 59 & 1 & 301 & 37 & 2 & 513 & 9 \\
\hline 6 & $\mathrm{~Kb} \mathrm{Mln}$ & 86 & 9,861 & 702 & - & - & - & - & - & - & 1 & 18 & 12 \\
\hline 7 & $\mathrm{~Kb} \mathrm{Blg}$ & 124 & 15,591 & 1,238 & 3 & 186 & 32 & 1 & 215 & 26 & 3 & 403 & 25 \\
\hline 8 & $\mathrm{~Kb} \mathrm{Nn}$ & 125 & 19,008 & 1,058 & 15 & 1,862 & 108 & - & - & - & 9 & 1,164 & 12 \\
\hline 9 & $\mathrm{~Kb} \mathrm{PPU}$ & 95 & 16,383 & 1,045 & 5 & 731 & 44 & - & - & - & 4 & 218 & 29 \\
\hline 10 & $\mathrm{~Kb} \mathrm{TT}$ & - & - & - & - & - & - & - & - & - & - & - & - \\
\hline 11 & Kt BP & 136 & 52,952 & 2,040 & 49 & 10,056 & 604 & 1 & 231 & 40 & 19 & 3,059 & 161 \\
\hline 12 & Kt Smrd & 198 & 71,756 & 3,266 & 38 & 10,820 & 639 & 2 & 1,363 & 114 & 15 & 3,904 & 145 \\
\hline 13 & $\mathrm{Kt} \mathrm{Tr}$ & 46 & 18,247 & 841 & 16 & 2,955 & 159 & - & - & - & 5 & 540 & 42 \\
\hline 14 & Kt Btg & 31 & 11,823 & 478 & 27 & 9,358 & 452 & - & - & - & 4 & 635 & 59 \\
\hline
\end{tabular}

Sumber : Kalimantan Timur Dalam Angka

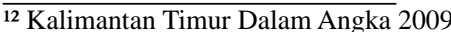

${ }^{13}$ Penyelenggaraan Pendidikan Wajar 12 Tahun, 2009-11-13, http://www.poskotakaltim.com/berita/read/2764masyarakat-kaltim-wajib-bangga.html 


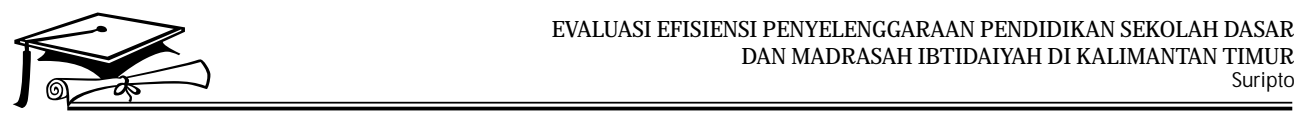

Tabel 1 menunjukan bahwa data penyelenggaraan pendidikan di Provinsi Kaltim yang diselenggarakan oleh pemerintah dan masyarakat sangat bervariasi. Secara keseluruhan, penyelenggaraan pendidikan 6 tahun ini masih didominasi oleh pemerintah. Namun demikian pada beberapa pemerintah daerah, masyarakat juga memiliki peran yang cukup besar seperti Kt Btg dan Kt BP. Hal lainnya yakni penyelenggaraan pendidikan jenis MI yang lebih banyak didominasi oleh partisipasi masyarakat dibandingkan dengan pemerintah. Selanjutnya terdapat beberapa kabupaten/kota tidak memiliki data seperti MI Negeri di $\mathrm{Kb} \mathrm{KB}, \mathrm{Kb} \mathrm{Nn}, \mathrm{Kb}$ PPU, Kt Tr, Kt Btg; SD swasta dan MI negeri di Kb Mln; seluruhnya di Kb TT. Sehingga dengan demikian, kabupaten dan kota tersebut tidak dilakukan evaluasi/diabaikan pada pembahasan selanjutnya.

\section{HASIL ANALISIS}

\section{Nilai Statistik Berdasarkan Data Input/Output}

Statistik ini disajikan dalam tiga jenis yakni secara parsial setiap jenis sekolah, secara gabungan negeri dan swasta dan secara gabungan SD dan MI. Nilai-nilai yang disajikan dalam statistik ini meliputi nilai maksimal, nilai minimal, nilai rata-rata dan standar deviasi. Nilai maksimal menunjukan nilai tertinggi yang digunakan dalam análisis dan sebaliknya. Nilai rata-rata merupakan besaran nilai jika dibagi rata pada setiap DMUs yang dianalisis. Selanjuntya nilai standar deviasi menunjukan variasi nilai indikator dalam analisis. Nilai statistik berdasarkan jenisnya seperti pada Tabel 2, Tabel 3 dan Tabel 4.

Tabel 2. Nilai Statistik, dan Standar Deviasi (Parsial)

\begin{tabular}{|c|c|c|c|c|c|}
\hline \multirow{2}{*}{ DMUs } & \multirow{2}{*}{ Indikator } & \multicolumn{3}{|c|}{ Nilai } & \multirow{2}{*}{$\begin{array}{l}\text { Standar } \\
\text { Deviasi }\end{array}$} \\
\hline & & Min. & Maks. & Rata-Rata & \\
\hline \multirow{3}{*}{ SD Negeri } & Sklh & 31 & 432 & 155 & 98 \\
\hline & $\mathrm{Gr}$ & 478 & 4.811 & 1.688 & 1.133 \\
\hline & $\mathrm{Sw}$ & 6.096 & 72.427 & 28.025 & 21.683 \\
\hline \multirow{3}{*}{ SD Swasta } & Sklh & 3 & 49 & 16 & 14 \\
\hline & $\mathrm{Gr}$ & 27 & 639 & 210 & 216 \\
\hline & $\mathrm{Sw}$ & 186 & 10.820 & 3.726 & 3.803 \\
\hline \multirow{3}{*}{ MI Negeri } & Sklh & 1 & 2 & 1,3 & 0,45 \\
\hline & $\mathrm{Gr}$ & 23 & 114 & 48 & 28 \\
\hline & $\mathrm{Sw}$ & 215 & 1.363 & 520 & 376 \\
\hline \multirow{3}{*}{ MI Swasta } & Sklh & 1 & 21 & 8 & 6 \\
\hline & $\mathrm{Gr}$ & 9 & 199 & 65 & 61 \\
\hline & Sw & 18 & 3.904 & 1.175 & 1.1437 \\
\hline
\end{tabular}

Sumber : Hasil Analisis DEA-BCC-Output

Tabel 2 menunjukan bahwa nilai standar deviasi dari setiap indikator besar, kecuali Sklh MI Negeri dan Sklh MI Swasta. Besarnya nilai standar deviasi menunjukan sangat bervariasinya data yang digunakan dalam analisis terutama Indikator Sw. Penyebaran Indikator SD Negeri dengan nilai minimal untuk sklh dan Gr berada di $\mathrm{Kt}$ Btg, sedangkan Sw berada di $\mathrm{Kb} \mathrm{Pr}$. Selanjuntya nilai maksimal berada di $\mathrm{Kb}$ 
KK. Penyebaran Indikator SD Swasta dengan nilai minimal untuk sklh dan sw berada di $\mathrm{Kb} \mathrm{Blg}$, nilai terendah gr berada di Kb Pr. Nilai tertinggi indikator sw dan gr berada di Kt Smrd, sklh berada di Kt BP. Penyebaran indikator MI Negeri dengan nilai minimal sw berada di $\mathrm{Kb} \mathrm{Blg}$ dan gr berada di gr. Nilai tertinggi berada di $\mathrm{Kt}$ Smrd. Penyebaran indikator MI Swasta dengan nilai minimal sklh dan sw berada di $\mathrm{Kb}$ Mln dan gr berada di $\mathrm{Kb} \mathrm{Br}$. Nilai tertinggi sklh dan gr berada di $\mathrm{Kb} \mathrm{KK}$ dan sw berada di Kt Smrd.

Tabel 3. Nilai Statistik, dan Standar Deviasi (Gabungan Negeri dan Swasta)

\begin{tabular}{cccccc}
\hline \multirow{2}{*}{ DMUs } & \multirow{2}{*}{ Indikator } & \multicolumn{3}{c}{ Nilai } & $\begin{array}{c}\text { Standar } \\
\text { Deviasi }\end{array}$ \\
\cline { 3 - 5 } & & Min. & Maks. & Rata-Rata & 98 \\
\hline \multirow{2}{*}{ SD N \& S } & Sklh & 58 & 447 & 171 & 1.205 \\
& Gr & 702 & 4.920 & 1.882 & 23.901 \\
& Sw & 6.592 & 82.576 & 31.464 & 7 \\
\multirow{2}{*}{ MI N \& S } & Sklh & 1 & 23 & 9 & 81 \\
& Gr & 12 & 259 & 90 & 1.464 \\
\hline
\end{tabular}

Sumber : Hasil Analisis DEA-BCC-Output

Tabel 3 menunjukan bahwa penyebaran indikator SD dengan nilai minimal sklh berada di $\mathrm{Kt} \mathrm{Btg}$, Sw berada di $\mathrm{Kb} \mathrm{Pr}$ dan $\mathrm{Gr}$ berada di $\mathrm{Kb}$ Mlnr. Nilai maksimal sklh dan gr berada di $\mathrm{Kb} \mathrm{KK}$, dan $\mathrm{Sw}$ berada di di Kt Smrd. Penyebaran nilai minimal indicator MI berada di Kb Mln. Nilai tertinggi indikator sklh berada di $\mathrm{Kb}$ KK dan indikator sw dang $r$ berdada di $\mathrm{Kb}$ Mln.
Gambaran tersebut menunjukan bahwa nilai terendah dan nilai tertinggi menyebar di DMUs. DMU yang memiliki nilai indikator sklh yang terendah belum tentu juga memiliki nilai sw atau gr yang terendah, begitu juga sebaliknya.

\section{Nilai Efisiensi DMUs}

Hasil analisis DEA-BCC-O menunjukan bahwa Nilai efisien secara gabungan dan parsial pada setiap DMU seperti pada Tabel 4.

Tabel 4. Nilai Efisien DMUs di Provinsi Kalimantan Timur

\begin{tabular}{|c|c|c|c|c|c|c|c|c|}
\hline \multirow[t]{2}{*}{ NO } & \multirow[t]{2}{*}{ DMUs } & \multicolumn{2}{|c|}{ SD } & \multicolumn{2}{|c|}{ MI } & \multicolumn{2}{|c|}{$\begin{array}{c}\text { Sekolah Negeri dan } \\
\text { Swasta }\end{array}$} & \multirow{2}{*}{$\begin{array}{c}\text { SD, MI } \\
\text { Negeri dan } \\
\text { SWasta }\end{array}$} \\
\hline & & Negeri & Swasta & Negeri & Swasta & SD & MI & \\
\hline 1 & $\mathrm{~Kb} \mathrm{Pr}$ & 0.18 & 1.00 & 1.00 & 0.81 & 0.21 & 0.96 & 1.00 \\
\hline 2 & $\mathrm{~Kb} \mathrm{~KB}$ & 0.56 & 0.62 & $\mathrm{X}$ & 0.29 & 0.62 & 0.51 & 1.00 \\
\hline 3 & $\mathrm{~Kb} \mathrm{KK}$ & 1.00 & 0.75 & 1.00 & 0.51 & 0.90 & 0.53 & 0.95 \\
\hline 4 & $\mathrm{~Kb} \mathrm{KT}$ & 0.50 & 0.78 & 1.00 & 0.62 & 0.56 & 1.00 & 1.00 \\
\hline 5 & $\mathrm{~Kb} \mathrm{Br}$ & 0.54 & 1.00 & 0.63 & 1.00 & 0.61 & 1.00 & 1.00 \\
\hline 6 & Kb Mln & 0.56 & $\mathrm{X}$ & $\mathrm{X}$ & 1.00 & 1.00 & 1.00 & 1.00 \\
\hline 7 & $\mathrm{~Kb} \mathrm{Blg}$ & 0.49 & 1.00 & 0.61 & 0.52 & 0.54 & 0.67 & 0.72 \\
\hline 8 & $\mathrm{~Kb} \mathrm{Nn}$ & 0.70 & 0.72 & $\mathrm{x}$ & 0.50 & 0.77 & 0,50 & 0.96 \\
\hline 9 & Kb PPU & 0.61 & 0.66 & $\mathrm{x}$ & 0.21 & 0.68 & 1.00 & 1.00 \\
\hline 10 & Kt BP & 1.00 & 0.95 & 0.46 & 0.78 & 1.00 & 0.81 & 1.00 \\
\hline 11 & Kt Smrd & 1.00 & 1.00 & 1.00 & 1.00 & 1.00 & 1.00 & 1.00 \\
\hline 12 & $\mathrm{Kt} \mathrm{Tr}$ & 1.00 & 0.82 & $\mathrm{x}$ & 0.42 & 0.94 & 0.80 & 1.00 \\
\hline 13 & Kt Btg & 1.00 & 1.00 & $\mathrm{x}$ & 0.61 & 1.00 & 0.58 & 1.00 \\
\hline
\end{tabular}

Sumber : Hasil Analisis DEA-BCC-Output 


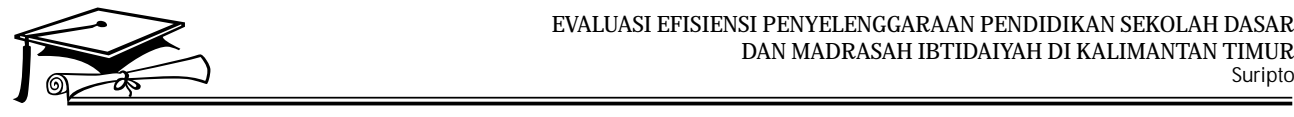

Hasil evaluasi SD negeri pada Tabel 4, DMUs memiliki average of scores sebesar 0.70 atau relatif belum efisien. DMUs yang memiliki nilai relatif efisien meliputi $\mathrm{Kb} \mathrm{KK}, \mathrm{Kt} \mathrm{BP}$, Kt Smrd, Kt Tr, Kt Btg. Sedangkan yang relatif tidak efisien meliputi $\mathrm{Kb}$ $\mathrm{Pr}, \mathrm{Kb} \mathrm{KB}, \mathrm{Kb} \mathrm{KT}, \mathrm{Kb} \mathrm{Br}, \mathrm{Kb} \mathrm{Mln}, \mathrm{Kb}$ $\mathrm{Blg}, \mathrm{Kb}$ Nn, dan Kb PPU. Selanjutnya DMU yang menjadi referensi dalam peningkatan efisiensi adalah Kt BPdan Kt Btg.

Hasil evaluasi SD swasta pada Tabel 4, DMUs memiliki average of scores sebesar 0.86 atau relatif belum efisien. DMUs yang memiliki nilai relatif efisien meliputi $\mathrm{Kb} \mathrm{Pr}, \mathrm{KtBr}, \mathrm{Kb}$ Blg, Kt Smrd, Kt Btg. Sedangkan yang relatif tidak efisien meliputi $\mathrm{Kb} \mathrm{KB}, \mathrm{Kb}$ $\mathrm{KK}, \mathrm{Kb} \mathrm{KT}, \mathrm{Kb} \mathrm{Nn}, \mathrm{Kb}$ PPU, Kt BP dan Kt Tr. Selanjutnya DMU yang menjadi referensi dalam peningkatan efisiensi adalah $\mathrm{Kb}$ Pr, Kb Br, Kb Blg, Kt Smrd, KtBtg.

Hasil evaluasi SD negeri dan swasta pada Tabel 4, DMUs memiliki average of scores sebesar 0.75 atau relatif belum efisien. DMUs yang memiliki nilai relatif efisien meliputi $\mathrm{Kb}$ Mln, Kt BP, Kr Smrd dan Kt Btg. Sedangkan yang relatif tidak efisien meliputi $\mathrm{Kb} \mathrm{Pr}, \mathrm{Kb} \mathrm{KB}, \mathrm{Kb} \mathrm{KK}, \mathrm{Kb}$, $\mathrm{KT}, \mathrm{Kb} \mathrm{Br}, \mathrm{Kb}$ Blg, Kb Nn, Kb PPU dan Kt Tr. Selanjutnya DMU yang menjadi referensi dalam peningkatan efisiensi adalah Kb BP, Kt Smrd dan Kb Btg

Hasil evaluasi MI negeri pada Tabel 4, DMUs memiliki average of scores sebesar 0.86 atau relatif belum efisien. DMUs yang memiliki nilai relatif efisien meliputi $\mathrm{Kb} \mathrm{Pr}, \mathrm{Kb} \mathrm{KK}$, Kb KT dan Kt Smrd. Sedangkan yang relatif tidak efisien meliputi $\mathrm{Kb} \mathrm{Br}, \mathrm{Kb}$ Blg dan Kt BP. Selanjutnya DMU yang menjadi referensi dalam peningkatan efisiensi adalah $\mathrm{Kb} \mathrm{Br}, \mathrm{Kb}$ Blg, dan $\mathrm{Kt}$ BP.

Hasil evaluasi MI swasta pada Tabel 4, DMUs memiliki average of scores sebesar 0.64 atau relatif belum efisien. DMUs yang memiliki nilai relatif efisien meliputi $\mathrm{Kb} \mathrm{Br}, \mathrm{Kb} \mathrm{Mln}$, dan Kt Smrd. Sedangkan yang relatif tidak efisien meliputi $\mathrm{Kb} \mathrm{Nn}, \mathrm{Kb} \mathrm{Pr}, \mathrm{Kb}$ $\mathrm{KB}, \mathrm{Kb} \mathrm{KK}, \mathrm{Kb} \mathrm{KT}, \mathrm{Kb} \mathrm{Blg}, \mathrm{Kb}$ PPU, $\mathrm{Kb}$ BP, Kt Tr, dan Kt Btg. Selanjutnya DMU yang menjadi referensi dalam peningkatan efisiensi adalah $\mathrm{Kb} \mathrm{Br}, \mathrm{Kb}$ $\mathrm{Blg}$, dan Kt BP.

Hasil evaluasi MI negeri dan swasta pada Tabel 4, DMUs memiliki average of scores sebesar 0.80 atau relatif belum efisien. DMUs yang memiliki nilai relatif efisien meliputi $\mathrm{Kb} \mathrm{KT}, \mathrm{Kb} \mathrm{Br}, \mathrm{Kb}$ Mln, Kb PPU, dan Kt Smrd. Sedangkan yang relatif tidak efisien meliputi $\mathrm{Kb} \mathrm{Pr}, \mathrm{Kb} \mathrm{KB}, \mathrm{Kb} \mathrm{Nn}$, $\mathrm{Kb} \mathrm{KK}, \mathrm{Kb} \mathrm{Blg}$, Kt BP, Kt Tr dan Kt Btg. Selanjutnya DMU yang menjadi referensi dalam peningkatan efisiensi adalah $\mathrm{Kb} \mathrm{Br}, \mathrm{Kb}$ KT dan Kt Smrd.

Hasil evaluasi Pendidikan Dasar 6 tahun yang meliputi SD negeri, SD swasta, MI negeri dan MI swasta pada Tabel 3, DMUs memiliki average of scores sebesar 0.97 atau relatif efisien. DMUs yang memiliki nilai relatif efisien meliputi $\mathrm{Kb} \mathrm{Pr}, \mathrm{Kb} \mathrm{KB}, \mathrm{Kb} \mathrm{KT}$, $\mathrm{Kb} \mathrm{Br}, \mathrm{Kb}$ Mln, Kb PPU, Kt BP, Kt Smrd, Kt Tr dan Kt Btg. Sedangkan yang relatif tidak efisien meliputi $\mathrm{Kb}$ $\mathrm{KK}, \mathrm{Kb} \mathrm{Blg}, \mathrm{Kb}$ Nn, dan. Selanjutnya DMU yang menjadi referensi dalam peningkatan efisiensi adalah $\mathrm{Kb} \mathrm{Pr}, \mathrm{KT}$, 
$\mathrm{Kb} \mathrm{Br}, \mathrm{Kb}$ Mln, Kt BP, Kt Btg dan Kt Smrd.

\section{Peta Efisiensi Indikator}

Tabel 4 menunjukan bahwa nilai efisiensi pendidikan 6 tahun Provinsi Kaltim sebesar 0,97 atau relatif efisien. Hal ini ditunjukan dengan hanya 3 DMUs yang memiliki nilai di kurang dari 1.00 (relatif efisien) dan nilai terendah sebesar 0.72. Hal ini berbeda dengan hasil analisis yang dilakukan secara parsial yang menunjukan bahwa nilai relatif efisiensinya lebih rendah jika dibandingkan dengan nilai secara gabungan. Pembahasan analisis selanjuntya akan difokuskan secara parsial. Hasil pemekataan indikator input dan output secara parsial seperti pada Tabel 5 .

Tabel 5. Peta Efisiensi Indikator

\begin{tabular}{|c|c|c|c|c|c|c|c|c|c|c|c|c|}
\hline \multirow{3}{*}{$\mathrm{Kb} / \mathrm{Kt}$} & \multicolumn{6}{|c|}{ SD } & \multicolumn{6}{|c|}{ MI } \\
\hline & \multicolumn{3}{|c|}{ Negeri } & \multicolumn{3}{|c|}{ Swasta } & \multicolumn{3}{|c|}{ Negeri } & \multicolumn{3}{|c|}{ Swasta } \\
\hline & sklh & Gr & Sw & sklh & $\mathrm{Gr}$ & Sw & sklh & $\mathrm{Gr}$ & Sw & sklh & $\mathrm{Gr}$ & $\mathrm{Sw}$ \\
\hline $\mathrm{Kb} \operatorname{Pr}$ & $\mathrm{X}$ & $\sqrt{ }$ & $\mathrm{X}$ & $\sqrt{ }$ & $\sqrt{ }$ & $\sqrt{ }$ & $\sqrt{ }$ & $\sqrt{ }$ & $\sqrt{ }$ & $\mathrm{X}$ & $\sqrt{ }$ & $\mathrm{x}$ \\
\hline $\mathrm{Kb} \mathrm{KB}$ & $\mathrm{x}$ & $\sqrt{ }$ & $\mathrm{x}$ & $\sqrt{ }$ & $\sqrt{ }$ & $\mathrm{x}$ & - & - & - & $\sqrt{ }$ & $X$ & $\mathrm{x}$ \\
\hline $\mathrm{Kb} \mathrm{KK}$ & $\sqrt{ }$ & $\sqrt{ }$ & $\sqrt{ }$ & $\mathrm{X}$ & $\sqrt{ }$ & $\mathrm{x}$ & $\sqrt{ }$ & $\sqrt{ }$ & $\sqrt{ }$ & $\mathrm{x}$ & $\mathrm{X}$ & $\mathrm{x}$ \\
\hline $\mathrm{Kb}$ KT & X & $\sqrt{ }$ & $\mathrm{X}$ & $\sqrt{ }$ & $\mathrm{X}$ & $\mathrm{x}$ & $\sqrt{ }$ & $\sqrt{ }$ & $\sqrt{ }$ & $\sqrt{ }$ & $\sqrt{ }$ & $\mathrm{x}$ \\
\hline $\mathrm{Kb} \mathrm{Br}$ & $\mathrm{X}$ & $\sqrt{ }$ & $\mathrm{x}$ & $\sqrt{ }$ & $\sqrt{ }$ & $\sqrt{ }$ & $\sqrt{ }$ & $\sqrt{ }$ & $\mathrm{X}$ & $\sqrt{ }$ & $\sqrt{ }$ & $\sqrt{ }$ \\
\hline Kb Mln & $\mathrm{X}$ & $\sqrt{ }$ & $\mathrm{x}$ & & - & - & - & - & - & $\sqrt{ }$ & $\sqrt{ }$ & $\sqrt{ }$ \\
\hline $\mathrm{Kb} \mathrm{Blg}$ & $\mathrm{X}$ & $\sqrt{ }$ & $\mathrm{x}$ & $\sqrt{ }$ & $\sqrt{ }$ & $\sqrt{ }$ & $\sqrt{ }$ & $\sqrt{ }$ & $\mathrm{X}$ & $\sqrt{ }$ & $X$ & $\mathrm{x}$ \\
\hline $\mathrm{Kb} \mathrm{Nn}$ & $\mathrm{x}$ & $\sqrt{ }$ & $\mathrm{x}$ & $\mathrm{x}$ & $\sqrt{ }$ & $\mathrm{X}$ & - & - & - & $\sqrt{ }$ & $X$ & $\mathrm{x}$ \\
\hline $\mathrm{Kb}$ PPU & $\mathrm{x}$ & $\sqrt{ }$ & $\mathrm{x}$ & $\sqrt{ }$ & $\sqrt{ }$ & $\mathrm{X}$ & - & - & - & $\sqrt{ }$ & $\sqrt{ }$ & $\mathrm{x}$ \\
\hline Kt BP & $\sqrt{ }$ & $\sqrt{ }$ & $\sqrt{ }$ & $\mathrm{X}$ & $\sqrt{ }$ & $\sqrt{ }$ & $\sqrt{ }$ & $\sqrt{ }$ & $\mathrm{x}$ & $\mathrm{X}$ & $X$ & $\mathrm{X}$ \\
\hline Kt Smrd & $\sqrt{ }$ & $\sqrt{ }$ & $\sqrt{ }$ & $\sqrt{ }$ & $\sqrt{ }$ & $\sqrt{ }$ & $\sqrt{ }$ & $\sqrt{ }$ & $\sqrt{ }$ & $\sqrt{ }$ & $\sqrt{ }$ & $\sqrt{ }$ \\
\hline $\mathrm{Kt} \mathrm{Tr}$ & $\sqrt{ }$ & $\sqrt{ }$ & $\sqrt{ }$ & $\mathrm{X}$ & $\sqrt{ }$ & $\mathrm{X}$ & - & - & - & $\sqrt{ }$ & $X$ & $\mathrm{X}$ \\
\hline Kt Btg & $\sqrt{ }$ & $\sqrt{ }$ & $\sqrt{ }$ & $\sqrt{ }$ & $\sqrt{ }$ & $\sqrt{ }$ & - & - & - & $\sqrt{ }$ & $X$ & $\mathrm{x}$ \\
\hline
\end{tabular}

Sumber: Hasil Analisis DEA-BCC-Output

Keterangan :

- : Tidak dievaluasi

$X$ : Relatif tidak efisien

$\sqrt{ }$ : Relatif Efisien

Tabel 5 menunjukan bahwa indicator gr SD negeri dan swasta, sklh dan gr MI negeri telah relatif efisien. Sedangkan, Kt Smrd merupakan DMU yang memiliki nilai indikator relatif paling efisien. Untuk mencapai nilai relatif efisien setiap indikator dapat ditingkatkan sesuai dengan proyeksi pada Tabel 6, Tabel 7 dan Tabel 8.

\section{Proyeksi Peningkatan Efisiensi Indikator Sekolah}

Proyeksi peningkatan efisiensi jumlah sekolah dikelompokan menjadi tiga jenis yakni SD Negeri, SD Swasta dan MI Swasta. SD Negeri meliputi Kb $\mathrm{Pr}, \mathrm{Kb} \mathrm{KB}, \mathrm{Kb} \mathrm{KT}, \mathrm{Kb} \mathrm{Br}, \mathrm{Kb}$ Mln, Kb $\mathrm{Blg}, \mathrm{Kb} \mathrm{Nn}$ dan $\mathrm{Kb}$ PPU. SD Swasta meliputi $\mathrm{Kb} \mathrm{KK}, \mathrm{Kb} \mathrm{Nn}$, Kt BP, dan Kt Tr. MI Swasta meliputi Kb Pr. Kb KK, dan Kt BP. Nilai proyeksi sekolah yang efisien berdasarkan analisis DEABCC-O seperti Tabel 6. 


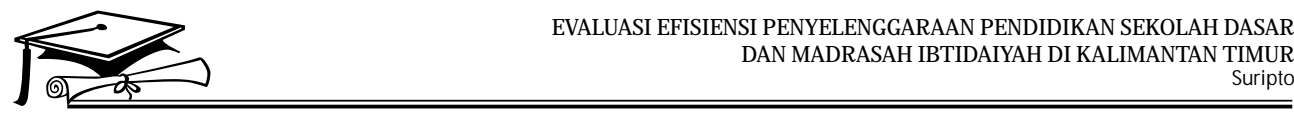

Tabel 6. Proyeksi Nilai Efisiensi Sekolah menurut DMUs

\begin{tabular}{|c|c|c|c|c|c|}
\hline \multirow[t]{2}{*}{ No. } & \multirow[t]{2}{*}{ DMU } & \multicolumn{2}{|c|}{ SD } & \multicolumn{2}{|c|}{ MI } \\
\hline & & Negeri & Swasta & Negeri & Swasta \\
\hline 1 & $\mathrm{~Kb} P \mathrm{Pr}$ & 89 & 4 & 1 & 11 \\
\hline 2 & $\mathrm{~Kb} \mathrm{~KB}$ & 109 & 5 & $\mathrm{x}$ & 5 \\
\hline 3 & Kb KK & 432 & 8 & 2 & 15 \\
\hline 4 & $\mathrm{~Kb} \mathrm{KT}$ & 125 & 14 & 1 & 4 \\
\hline 5 & $\mathrm{~Kb} \mathrm{Br}$ & 107 & 5 & 1 & 2 \\
\hline 6 & Kb Mln & 46 & $\mathrm{x}$ & $\mathrm{x}$ & 1 \\
\hline 7 & Kb Blg & 82 & 3 & 1 & 3 \\
\hline 8 & $\mathrm{~Kb} \mathrm{Nn}$ & 70 & 8 & $\mathrm{x}$ & 9 \\
\hline 9 & $\mathrm{~Kb}$ PPU & 69 & 5 & $\mathrm{x}$ & 4 \\
\hline 10 & Kt BP & 136 & 36 & 1 & 15 \\
\hline 11 & Kt Smrd & 198 & 38 & 2 & 15 \\
\hline 12 & $\mathrm{Kt} \mathrm{Tr}$ & 46 & 11 & $\mathrm{x}$ & 5 \\
\hline 13 & $\mathrm{Kt} \mathrm{Btg}$ & 31 & 27 & $\mathrm{x}$ & 4 \\
\hline
\end{tabular}

Sumber : Hasil Analisis DEA-BCC-Output

Proyeksi pada Tabel 6 dibandingkan dengan nilai pada Tabel 1, maka besar nilai yang perlu dikurangi sebagai berikut:

- Sekolah SD Negeri di Kb Pr sebanyak 129 unit, Kb KB sebanyak 109, Kb KT sebanyak 36 unit, Kb $\mathrm{Br}$ sebanyak 44 unit, $\mathrm{Kb} \mathrm{Blg}$ sebanyak 42 unit, $\mathrm{Kb}$ Nn sebanyak 55 unit, dan Kb PPU sebanyak 24 unit.

- Sekolah SD Swasta di Kb KK sebanyak 7 unit, Kb Nn sebanyak 7 unit, Kt BP sebanyak 13 unit, dan Kt Tr sebanyak 5 unit.

- Sekolah MI Swasta di Kb KK sebanyak 15 unit dan Kt BP sebanyak 4 unit.

Proyeksi jumlah sekolah secara parsial dibandingkan dengan nilai efisiensi secara kolektif pada Tabel 4 terdapat kesesuaian, dimaka Kb KT, Kb $\mathrm{Blg}$ dan $\mathrm{Kb} \mathrm{Nn}$ diukur relatif belum efisien. Namun demikian, pengurangan jumlah sekolah untuk mencapai tingkat relatif efisien bukan pilihan yang baik. Dimana, hal tersebut akan bertentangan dengan semangat untuk memperluas dan mempermudah akses pendidikan. Hasil tersebut tentunya tidak terlepas dari kondisi geografis, luas wilayah dan penyebaran penduduk di Provinsi Kaltim. Sebagai Contoh kepadatan penduduk di $\mathrm{Kb}$ KT sebanyak 6,01 / $\mathrm{Km}^{2}, \mathrm{~Kb}$ Blg sebanyak $6,65 / \mathrm{Km}^{2}, \mathrm{~Kb}$ $\mathrm{Nn}$ sebanyak $9,58 / \mathrm{Km}^{2}$. Sehingga dengan hal-hal tesebut, maka dalam pembangunan sekolah perlu mempertimbangkan lokasi yang paling mudah diakses semua penduduk.

\section{Proyeksi Peningkatan Efisiensi Indikator Siswa}

Proyeksi peningkatan efisiensi jumlah siswa dikelompokan menjadi empat jenis yakni SD Negeri, SD Swasta, MI Negeri dan MI Swasta. SD Negeri meliputi $\mathrm{Kb} \mathrm{Pr}, \mathrm{Kb} \mathrm{KB}, \mathrm{Kb} \mathrm{KT}$, $\mathrm{Kb} \mathrm{Br}, \mathrm{Kb}$ Mln, $\mathrm{Kb} \mathrm{Blg}, \mathrm{Kb} \mathrm{Nn}$ dan $\mathrm{Kb}$ PPU. SD Swasta meliputi Kb KB, Kb 
$\mathrm{KK}, \mathrm{Kb} \mathrm{KT}, \mathrm{Kb} \mathrm{Nn}$, dan Kb PPU. MI Negeri meliputi $\mathrm{Kb} \mathrm{Br}, \mathrm{Kb} \mathrm{Blg}$, Kt BP, dan Kt Tr. MI Swasta meliputi Kb Pr. $\mathrm{Kb} \mathrm{KB}, \mathrm{Kb} \mathrm{KK}, \mathrm{Kb} \mathrm{KT}, \mathrm{Kb} \mathrm{Blg}, \mathrm{Kb}$
Nn, Kb PPU, Kt BP, Kt Tr, dan Kt Btg. Nilai proyeksi siswa yang efisien berdasarkan analisis DEA-BCC-O seperti Tabel 7.

Tabel 7. Proyeksi Nilai Efisiensi Siswa menurut DMUs

\begin{tabular}{clcccc}
\hline \multirow{2}{*}{ No. } & DMU & \multicolumn{3}{c}{ SD } & MI \\
\cline { 3 - 6 } & & Negeri & Swasta & Negeri & Swasta \\
\hline 1 & Kb Pr & 3.4652 & 496 & 629 & 2.407 \\
\hline 2 & Kb KB & 42.341 & 1.462 & X & 1.296 \\
\hline 3 & Kb KK & 72.427 & 2.622 & 583 & 3.904 \\
\hline 4 & Kb KT & 48.634 & 4.798 & 320 & 1.019 \\
5 & Kb Br & 41.603 & 1640 & 475 & 513 \\
6 & Kb Mln & 17.721 & X & X & 18 \\
7 & Kb Blg & 31.835 & 186 & 353 & 774 \\
8 & Kb Nn & 27.095 & 2.602 & x & 1.164 \\
\hline 9 & Kb PPU & 26.753 & 1.104 & X & 1019 \\
10 & Kt BP & 52.952 & 10.546 & 508 & 3.904 \\
11 & Kt Smrd & 71.756 & 10.820 & 1.363 & 3.904 \\
12 & Kt Tr & 18.247 & 3.604 & x & 1.296 \\
13 & Kt Btg & 11.823 & 9.358 & x & 1.035 \\
\hline
\end{tabular}

Sumber : Hasil Analisis DEA-BCC-Output

Proyeksi pada Tabel 7 dibandingkan dengan nilai pada Tabel 1 , maka besar nilai yang perlu ditambah sebagai berikut :

- Siswa SD Negeri di Kb Pr ditambah sebanyak 28.556 orang, $\mathrm{Kb} \mathrm{KB}$ sebanyak 18.734, Kb KT sebanyak 24.362 orang, $\mathrm{Kb} \mathrm{Br}$ sebanyak 19.298, Kb Mln sebanyak 7.860 orang, $\mathrm{Kb} \mathrm{Blg}$ sebanyak 16.243 orang, $\mathrm{Kb} \mathrm{Nn}$ sebanyak 8.086 orang, Kb PPU sebanyak 16.383 orang

- Siswa SD Swasta di Kb KB ditambah sebanyak 551 orang, $\mathrm{Kb}$ KK sebanyak 668 orang, Kb KT sebanyak 1.058 orang, $\mathrm{Kb} \mathrm{Nn}$ sebanyak 740orang, Kb PPU sebanyak 373 orang, Kt BP sebanyak 490 orang, dan $\mathrm{Kt} \mathrm{Tr}$ sebanyak 649 orang.
- Siswa MI Negeri Kb Br sebanyak 174 orang, Kb Blg sebanyak 138 orang, dan Kt BP sebanyak 277 orang.

- MI Swasta di Kb Pr ditambah sebanyak 626 orang, $\mathrm{Kb} \mathrm{KB}$ sebanyak 915 orang, $\mathrm{Kb} \mathrm{KK}$ sebanyak 1.881 orang, $\mathrm{Kb} \mathrm{KT}$ sebanyak 389 orang, $\mathrm{Kb} \mathrm{Blg}$ sebanyak 371 orang, Kb PPU sebanyak 801 orang, Kt BP sebanyak 845 orang, Kt Btg sebanyak 400 orang, dan $\mathrm{Kt} \mathrm{Tr}$ sebanyak 756 orang.

Selanjuntya, jumlah penduduk dengan usia antara 5- 14 tahun sebanyak 594.600 dan pertumbuhan penduduk sebesar 2,31 persen, maka hasil perhitungan kasar dengan membandingkan jumlah siswa sekolah 
pendidikan 6 tahun dengan kelompok usia tersebut masih terdapat lebih dari 150 ribu yang belum menikmati pendidikan 6 tahun. Sehingga dengan demikian setiap DMUs dapat meningkatkan sesuai proyeksi tersebut diatas.

\section{Proyeksi Peningkatan Efisiensi Indikator Guru}

Proyeksi peningkatan efisiensi

Tabel 8. Proyeksi Nilai Efisiensi Guru menurut DMUs

\begin{tabular}{clcccc}
\hline No. & DMU & \multicolumn{3}{c}{ SD } & MI \\
\cline { 3 - 6 } & & Negeri & Swasta & Negeri & Swasta \\
\hline 1 & Kb Pr & 1.345 & 27 & 51 & 76 \\
2 & Kb KB & 1.637 & 54 & X & 40 \\
3 & Kb KK & 4.811 & 109 & 43 & 145 \\
4 & Kb KT & 1.876 & 220 & 23 & 29 \\
5 & Kb Br & 1.609 & 59 & 37 & 9 \\
6 & Kb Mln & 702 & $\mathrm{X}$ & $\mathrm{X}$ & 12 \\
7 & Kb Blg & 1.238 & 32 & 26 & 20 \\
8 & Kb Nn & 1.058 & 108 & $\mathrm{x}$ & 12 \\
9 & Kb PPU & 1.045 & 44 & $\mathrm{x}$ & 29 \\
10 & Kt BP & 2.040 & 604 & 40 & 145 \\
11 & Kt Smrd & 3.266 & 639 & 114 & 145 \\
12 & Kt Tr & 841 & 159 & X & 40 \\
13 & Kt Btg & 478 & 452 & x & 30 \\
\hline
\end{tabular}

Sumber : Hasil Analisis DEA-BCC-Output

Proyeksi pada Tabel 8 dibandingkan dengan nilai pada Tabel 1 menunjukan bahwa jumlah guru di SD Negeri dan MI Negeri telah relatif efisien. Selanjuntya, kebutuhan pengurangan jumlah guru SD dan MI swasta sebagai berikut:

- Guru SD Swasta di Kb KT perlu dikurangi sebanyak 15 unit.

- Guru MI Swasta di Kb KB kurangi sebanyak 3 orang, Kb KK sebanyak 54 orang, Kb Blg sebanyak 5 orang, Kt BP sebanyak 16 orang, Kt Btg sebanyak 29 orang dan $\mathrm{Kt} \mathrm{Tr}$ sebanyak 2 orang jumlah guru dikelompokan menjadi dua jenis yakni SD Swasta dan MI Swasta. SD Swasta yang relatif belum efisien adalah $\mathrm{Kb} \mathrm{KT}$. MI Swasta meliputi $\mathrm{Kb} \mathrm{KB}, \mathrm{Kb} \mathrm{KK}, \mathrm{Kb} \mathrm{Blg}, \mathrm{Kt}$ BP, Kt Btg dan Kt Tr. Nilai proyeksi guru yang efisien berdasarkan analisis DEA-BCC-O seperti Tabel 8.

Penyelenggaraan sekolah swasta berdasarkan Tabel 4 sebagian besar memiliki nilai relatif tidak efisien. Terkait dengan indikator jumlah guru, kebijakan dalam pengurangan guru sekolah swasta bukanlah menjadi kewenangan dari pemerintah daerah. Selain itu, belum meratanya penyebaran guru-guru di daerah terpencil juga menjadi permasalahan lainnya. Oleh karena itu, pemerintah daerah perlu mengeluarkan kebijakan yang mampu meningkatkan efektifitas dan efisiensi sekolah swasta. Kebijakan tersebut antara lain bantuan dalam 
pengadaaan fasilitas sarana seperti buku untuk siswa, dan lain sebagainya.

\section{DMU Rujukan}

Hasil analisa secara gabungan menunjukan bahwa Kt Smrd menjadi rujukan paling banyak. Analisa secara parial, Kt Smrd menunjukan semua jenis pendidikan memiliki nilai relatif efisien. Setiap DMU rujukan dalam meningkatkan efisiensi DMU bersangkutan merupakan DMU yang paling mendekati dan memiliki karakteristik hampir sama. Selanjuntya rujukan secara rinci untuk setiap jenis pendidikan dan DMU seperti pada Tabel 9.

Tabel 9. DMUs Rujukan Dalam Meningkatkan Efisiensi

\begin{tabular}{|c|c|c|c|c|c|}
\hline \multirow[t]{2}{*}{ No. } & \multirow[t]{2}{*}{ DMU } & \multicolumn{2}{|c|}{ Rujukan SD } & \multicolumn{2}{|c|}{ Rujukan MI } \\
\hline & & Negeri & Swasta & Negeri & Swasta \\
\hline 1 & $\mathrm{~Kb} \operatorname{Pr}$ & $\mathrm{Kt} \mathrm{BP}, \mathrm{Kt} \mathrm{Btg}$ & - & - & $\begin{array}{c}\mathrm{Kb} \mathrm{Br}, \mathrm{Kb} \mathrm{Nn} \\
\text {, Kt Smrd }\end{array}$ \\
\hline 2 & $\mathrm{~Kb} \mathrm{~KB}$ & Kt BP, Kt Btg & $\mathrm{Kb}$ Pr, $\mathrm{Kb} \mathrm{Br}$. & - & $\begin{array}{c}\mathrm{Kb} \mathrm{Br}, \mathrm{Kt} \\
\text { Smrd }\end{array}$ \\
\hline 3 & $\mathrm{~Kb} \mathrm{KK}$ & - & $\mathrm{Kb} \mathrm{Br}, \mathrm{Kt} \mathrm{Btg}$ & - & Kt Smrd \\
\hline 4 & $\mathrm{~Kb} \mathrm{KT}$ & $\mathrm{Kb}$ BP, Kt Btg & $\mathrm{Kb} \mathrm{Br}, \mathrm{Kt} \mathrm{Btg}$ & - & $\mathrm{Kb} \mathrm{Br}, \mathrm{Kb} \mathrm{Nn}$ \\
\hline 5 & $\mathrm{~Kb} \mathrm{Br}$ & $\mathrm{Kb} \mathrm{BP}, \mathrm{Kt} \mathrm{Btg}$ & - & $\mathrm{Kb} \mathrm{Br}, \mathrm{Kb} \mathrm{Nn}$ & - \\
\hline 6 & Kb Mln & $\mathrm{Kb}$ BP, Kt Btg & - & - & - \\
\hline 7 & $\mathrm{~Kb} \mathrm{Blg}$ & $\mathrm{Kb}$ BP, Kt Btg & - & $\mathrm{Kb}$ Pr, Kb KT & $\begin{array}{c}\mathrm{Kb} \mathrm{Br}, \mathrm{Kt} \\
\text { Smrd }\end{array}$ \\
\hline 8 & $\mathrm{~Kb} \mathrm{Nn}$ & $\mathrm{Kb} \mathrm{BP}, \mathrm{Kt}$ Btg & $\mathrm{Kb} \mathrm{Br}, \mathrm{Kt} \mathrm{Btg}$ & - & - \\
\hline 9 & $\mathrm{~Kb}$ PPU & $\mathrm{Kb}$ BP, Kt Btg & $\mathrm{Kb} \mathrm{Br}, \mathrm{Kt} \mathrm{Btg}$ & - & $\begin{array}{c}\mathrm{Kb} \mathrm{Br}, \mathrm{Kb} \mathrm{Nn} \\
\mathrm{Kt} \mathrm{Smrd}\end{array}$ \\
\hline 10 & Kt BP & - & $\begin{array}{c}\text { Kt Smrd, Kt } \\
\text { Btg }\end{array}$ & $\mathrm{Kb} \mathrm{Pr}, \mathrm{Kb} \mathrm{KT}$ & Kt Smrd \\
\hline 11 & Kt Smrd & - & - & - & - \\
\hline 12 & Kt Tr & & $\mathrm{Kb} \mathrm{Br}, \mathrm{Kt} \mathrm{Btg}$ & & $\begin{array}{l}\mathrm{Kb} \mathrm{Br}, \mathrm{Kt} \\
\text { Smrd }\end{array}$ \\
\hline 13 & Kt Btg & - & - & - & $\begin{array}{c}\mathrm{Kb} \mathrm{Br}, \mathrm{Kt} \\
\text { Smrd }\end{array}$ \\
\hline
\end{tabular}

Sumber : Hasil Analisis DEA-BCC-Output

Berdasarkan Tabel 9, maka rujukan SD negeri dan swasta lebih banyak merujuk pada Kt BP dan Kt Btg. Rujukan MI negeri paling banyak Kb KT dan Kb Pr sedangkan MI Swasta paling banyak merujuk pada Kt Smrd.

\section{E. PENUTUP}

Berdasarkan hasil analisis dan pembahasan tersebut diatas, maka dapat disimpulkan hal-hal sebagai berikut:

- Nilai relatif efisien Pendidikan 6 Tahun Provinsi Kaltim sebesar 0,97 yang artinya relatif efisien. Sebanyak 10 DMUs memiliki nilai relatif efisien dan 3 DMUs relatif belum efisien. DMUs yang relatif efisien meliputi $\mathrm{Kb} \mathrm{Pr}, \mathrm{Kb} \mathrm{KB}, \mathrm{Kb}$ 
$\mathrm{KT}, \mathrm{Kb} \mathrm{Br}, \mathrm{Kb}$ Mln, Kb PPU, Kt BP, Kt Smrd, Kt Tr, Kt Btg.

- Hasil evaluasi secara parsial menunjukan bahwa SD negeri sebanyak 5 DMUs relatif efisien dan 8 DMUs relatif belum efisien; SD Swasta sebanyak 5 DMUs relatif efisien dan 7 DMUs relatif belum efisien dan 1 DMU tidak dievaluasi; MI Negeri sebanyak 4 DMUs relatif efisien dan 3 DMUs relatif belum efisien dan 6 DMU tidak dievaluasi; dan MI Swasta sebanyak 4 DMUs relatif efisien dan 9 DMUs relatif belum efisien;

- DMUs yang memiliki nilai relatif efisien secara gabungan dan parsial adalah Kt Smrd.

- DMU Rujukan secara gabungan paling banyak adalah Kt Smrd. Secara parsial, SD negeri dan swasta adalah Kt BP dan Kt Btg, MI negeri paling banyak $\mathrm{Kb} \mathrm{KT}$ dan $\mathrm{Kb}$ Pr, sedangkan MI Swasta paling banyak merujuk pada Kt Smrd.

Hasil analisis tersebut diatas tentunya masih memiliki kelemahan dan kekurangan. Kajian ini hanya didasarkan atas data-data sekunder yang masih membutuhkan cross chek dengan berbagai pihak yang terlibat dalam pendidikan di Provinsi Kaltim. Namun demikian, dari hasil analisis secara gabungan memiliki nilai relatif efisien. Hal ini menunjukan bahwa pembangunan pendidikan 6 tahun di Provinsi Kaltim telah relatif efisien. Namun jika dibandingkan dengan hasil secara parsial maka masih banyak DMU yang belum efisien. Kondisi tersebut menunjukan bahwa penyebaran jumlah sekolah, guru dan siswa pada setiap DMUs relatif belum merata. Tentunya hal tersebut tidak terlepas dari kondisi geografis serta penyebaran penduduk yang tidak merata di Provinsi Kaltim. Sehingga dengan demikian dalam meningkatkan efisiensi DMU yang lebih optimal disarankan sebagai berikut :

- Meningkatkan dalam kemudahan akses pendidikan dengan membangun sarana pendidikan yang mudah dijangkau oleh setiap penduduk.

- Pemerataan guru yang proposional sesuai kebutuhan setiap DMU (wilayah/sekolah)

- Membuat / merelokasi penduduk yang tersebar (berjauhan tempat tinggal) untuk menjadi satu wilayah se hingga memudahkan memberikan fasilitas sarana pendidikan.

\section{DAFTAR PUSTAKA}

Cooper, William W., Seiford, Lawrence M., and Tone, Kaoru, 2006, Data Envelopment Analysis : A Comprehensive Text With Models, Applications, References and Dea-Solver Software, New York: Springer.

, Steering Committee fot The Review of Commonwealth/State Service Provision, 1997, Data Analysis : A technique for measuring the efficiency of government service delivery, AGPS, Canbera, Australia 
BPS Kalimantan Timur, 2010, Kalimantan Timur Dalam Angka 2009, S a marinda: B PS Kalimantan Timur.

Bappeda Kalimantan Timur, 2008, Rencana Pembangunan Jangka Menengah (RPJM) Daerah Provinsi Kalimantan Timur 2009 - 2013, Samarinda: Bappeda Kalimantan Timur.

Bahtiar, Toni, 2009, Materi Metodologi dan Alat Analisis Kajian Evaluasi Pelayanan Dasar, Jakarta: Pusat Kajian Kinerja $\mathrm{Ke} \mathrm{le} \mathrm{mbaga} \mathrm{an,} \mathrm{tidak}$ dipublikasikan.

Suripto, 2010, Evaluasi Kinerja Pendidikan Dasar Kabupaten Dan Kota di Provinsi Gorontalo, Jakarta, (diterima di Jurnal Ilmu Administrasi STIALAN Jakarta).

http://www.diknas.go.id/headline.php ?id=143 : Mendiknas: Pendidikan Dasar Gratis Bisa Dilaksanakan) diunduh tanggal 27 November 2010

http://www.um.ac.id/news/2010/03/ 348/: Program membangun pendidikan di Kalimantan Timur, Orasi Ilmiah Gubernur Kalimantan Timur Pada Upacara Wisuda Um Semester Gasal 2009/2010 diunduh tanggal 27 November 2010

http://www.indonesia.go.id/id/index.p hp?option=com_content\&task= view \&id=9938\&Itemid=831: Kaltim Salurkan Beasiswa
Rp 94,241 Miliar diunduh tanggal 27 November 2010

http://www.um.ac.id/news/2010/03/ 348/: Kondisi Terkini Pendidikan Kaltim, Orasi Ilmiah Gubernur Kalimantan Timur Pada Upacara Wisuda Um Semester Gasal 2009/2010 diunduh tanggal 27 November 2010

http://mrtoy09.com/index.php?option $=$ com_content $\& v i e w=$ article $\& \mathrm{i}$ $\mathrm{d}=75:$ i s u - i s u - k ritis dalampendidikan\&catid $=43:$ arti kelku\&Itemid $=6$ : Sarana Dan Prasarana Pendidikan Di Kalimantan Timur, diunduh tanggal 27 November 2010

http://www.poskotakaltim.com/berita/ $\mathrm{read} / 2764$-masyarakat-kaltimw a j i b - b a n g g a . h t m l: Penyelenggaraan Pendidikan Wajar 12 tahun. diunduh tanggal 27 November 2010

http://kaltim.bps.go.id/ diakses tanggal 27 November 2010

http://www.bappedakaltim.com/downl o ad - center/rpjm/R P J M Provinsi-Kaltim-2009---2013/ diunduh tanggal 27 November 2010

Http://www.kaltimpost.co.id/index.ph p? mib=berita.detail\&id $=79928$ diunduh 17 Februari 2011

http://puslitjaknov.org/data/file/2008/ makalah_peserta/02_totok\% $20 \mathrm{~s}$ _kajian\%20penyelenggaraan $\% 2$ 0 akreditasi $\% 20$ sekolah.pdf diunduh 17 Februari 2011 